\title{
Rural Policy in Scotland after Devolution
}

Michael Keating (European University Institute and University of Aberdeen) and Linda Stevenson (University of Aberdeen)

Department of Social and Political Sciences

European University Institute

Badia Fiesolana

50016 S. Domenico di Fiesole

ITALY

Keating@iue.it

Revised version for Regional Studies, January 2005 


\section{Rural Policy in Scotland after Devolution}

KEYWORDS: Rural policy; devolution; Scotland

JEL classifications: RO, QO

Abstract

Governments across Europe, encouraged by the European Union, are moving from an agriculture policy, defined in sectoral terms, to rural policy, with a spatial focus. Rural policy is a transversal policy, linking a number of sectoral concerns and interests. This makes it an interesting study, both of changing policy networks under devolution in the United Kingdom, and of the extent of policy distinctiveness in Scotland. Rural and agriculture policy are devolved in Scotland but also highly Europeanized. Devolution has led to a change in political and administrative structures and in policy communities, which are now more distinct and self-contained in Scotland. Scotland has gone its own way on several important issues, but Europe is a force for convergence of policy within the UK. Rural policy is still dominated by agriculture, and Scottish policy emphasizes maintaining the small farmers. There is, however, some evidence of a broadening of the agenda.

\section{Introduction}

Rural policy has come onto the agenda across Europe, because of the reform of the Common Agricultural Policy (CAP) and the declining influence of the farming lobbies. Yet rural policy is an open category rather than a pre-defined agenda, and much work remains to be done in defining and measuring problems and issues. It is a cross-cutting or transversal policy, linking a number of sectoral concerns and competing interests. This makes it an interesting study, both of changing policy networks under devolution in the United Kingdom, and of policy distinctiveness in 
Scotland. The main instruments of rural policy are devolved in Scotland but also Europeanized, which brings Whitehall back into the negotiations. In this article, we ask how the institutions and policy communities have adapted to the new rural focus and how this has affected policy in Scotland so far. First, we examine the emergence of rural policy as an issue. Then we look at the changing policy networks in Scotland after devolution. Finally, we consider policy development under four headings: general rural policies, where there is scope for redefining issues and approaches in Scotland; agricultural issues coming under the EU; the Foot and Mouth crisis as an issue requiring close co-ordination between Scotland and England; and separate policies, where Scotland has gone its own way without reference to the UK level. We find evidence both of new policy networks within Scotland and of Scottish autonomy with respect to the UK level, but this varies by issue. The weight of pre-devolution interests and practices still influences policy development.

\section{The Emergence of Rural Policy}

While there is a long history of policy for rural areas of Scotland, usually focussed on the Highlands, general rural policy is a relative newcomer. It contains various themes. One is linked to agriculture, the re-territorialization of food production (WARD and LOWE, 2002) and the need to place it in the context of the broader rural economy. There is an emphasis on the environment as a national and global asset and the need to conserve it for its own sake and for recreation. Another theme is linked to identity, which may be connected with the notion of rurality as an aspect of tradition (WARD and LOWE, 2002) or to national identity. In the United Kingdom, the symbolic and identity aspects of the rural areas are vital elements in the self-definition of the constituent nations. Finally, rural policy may be defined functionally as the impact on 
rural areas of sectoral issues like community sustainability, housing, health, transport or education. This broad definition draws into rural policy networks a wide variety of groups with competing interests and tends to increase politicization and conflict. It also means that rural policy communities will overlap with other ones, that groups may have a choice of which channels to use and that some issues of vital concern to rural areas may remain outside 'rural policy' networks.

Rural policy came onto the UK political agenda largely as a result of the crisis in agriculture and reform of the Common Agricultural Policy. This involved a move from price supports to explicit subsidies for farmers, and then from supporting production to supporting farmers as custodians of the land. The EU, along with national governments, is now trying to broaden the focus of farming beyond the farmgate, towards diversification and rural development generally (BRYDEN, 2000; KEATING, 2000). In the United Kingdom, the model of intensive, industrialized agriculture, particularly prevalent in England, was dramatically challenged by the outbreak of BSE (mad cow disease) in the 1990s. This undermined the agricultural departments and their link to the farming lobby and helped the advocates of alternative approaches. No sooner was the BSE crisis over than Britain suffered a severe outbreak of Foot and Mouth Disease lasting most of 2001 and whose cost to non-farming interests in the countryside, notably tourism, far outweighed the cost to agriculture itself.

\section{Conditions of Rural Scotland}

Farming accounts for 1.4 per cent of GDP and 1.6 per cent of employment in Scotland, against 0.9 per cent of both GDP and of employment in England. Twenty per cent of farming land in England is Less Favoured Area, compared with 84 per 
cent in Scotland (of which 98 per cent is Seriously Disadvantaged) (MAFF, 2001; SCOTTISH EXECUTIVE, 2001). Scotland is thus more dependent on CAP support for agriculture than is England and has fewer possibilities for higher value-added speciality farming. The population of England has steadily grown, expanding by six per cent between 1971 and 1996, while the rural population went up by 24 per cent (MAFF, 2001). Scotland has stagnated demographically since the mid-twentieth century and the move to rural areas has been less dramatic. Between 1981 and 1991 its population fell by 1.4 per cent, while its rural population increased by 3.5 per cent (SHUCKSMITH, 2000). Rural England has faced pressures for urban expansion and housing, especially in the south, so that conservation and development control are important issues. In most of rural Scotland, by contrast, the emphasis has been on promoting economic development and retaining the population, especially in the Highlands, where a distinct culture and way of life are at stake. As important as the objective differences are the social constructions and uses of rurality, such as the 'rural idyll' focused on traditional agriculture and social relations, which was part of the English stereotype but which has less resonance in other parts of the United Kingdom (WOODWARD and HALFACREE, 2002). Scottish identity does indeed incorporate rural images but these are less clearly linked to agriculture (MACAULAY LAND RESEARCH INSTITUTE, 2001), and differ between the Highlands and Lowlands.

Scotland has the most concentrated land ownership in Europe, with 608 people owning fifty per cent of the land, ten per cent of which is owned by a mere eighteen landowners (CALLENDER, 1997). This has been a political issue since the early nineteenth century, landowners were blamed for obstructing modernization during the twentieth century and land reform has remained a periodic preoccupation of the 
political left. Land reform is also historically linked into the issue of home rule (KEATING and BLEIMAN, 1979). Over recent years, many estates have come into foreign ownership and are run on capitalist lines, often as sporting ventures, raising concerns about foreigners buying up Scotland. Controversies rage about the economics of sporting estates, sometimes portrayed as a form of consumption which contributes little to the local economy, and at other times as profitable enterprises (WIGHTMAN and HIGGINS, 2000).

Many individual Scottish farms are small and there are few of the big agribusiness concerns found in southern England. Conditions in the Highlands differ from those in the Lowlands, as do systems of tenure. Crofting, a form of smallholding supporting part-time farmers, was given legislative protection in the late nineteenth century, but only in the Highlands and Islands, and has been the subject of repeated attention again since the 1960s. The Highlands has been subject to other special measures of intervention, notably the Highlands and Islands Development Board (now Highlands and Islands Enterprise). Unlike most of rural Scotland and England, the Highlands and Islands are also eligible for regional assistance under both British and EU rules; indeed under the 1994-99 Structural Funds regime they were an Objective One area. Political pressures also vary across the United Kingdom. Agriculture and rural affairs have a particularly high salience in Wales and Northern Ireland followed by Scotland. Of the twenty parliamentary constituencies with the highest percentage of workers in agriculture, seven are in Wales, four in Scotland and two in Northern Ireland (WALLER and CRIDDLE, 2002). Since the late 1990s, there has been a mobilization of rural dwellers, mainly in England, around the Countryside Alliance, alarming the Labour Party which now holds seats in rural areas. A rural group of Labour MPs was formed in 1997, producing Rural Audit: A Health Check on Rural 
Britain, in 1999 with the support of a number of English organizations. In Scotland, this lobby has been less prominent, but rural policy has been placed on the agenda by the Liberal Democrats, coalition partners of Labour, who hold most of their seats in the rural areas. These distinct political situations have led to significant differences in the way the question is approached.

\section{Rural Policy and Devolution}

Under the Scottish devolution settlement of 1999 only powers reserved to the central parliament at Westminster are specified. Reserved powers do not include agriculture, or the sectoral categories relevant to rural policy like health, education, transport and housing, although there are some reservations on regional policy and aid to firms.

Devolution builds on a long history of administrative decentralization to the Scottish Office and other agencies, continued even under Conservative governments in the 1990s, who, for example, broke up the Nature Conservancy Council into separate territorial agencies (WARD, 2000). As a result, over many rural policy fields there is no British central department, but a series of territorial ones, with the English usually the largest and taking the lead on remaining UK matters.

Agriculture, environmental policy and, to a lesser extent, rural development are also Europeanized through the Common Agricultural Policy including the Rural Development Regulation, and EU environmental policy. The devolution legislation allows Scotland, Wales and Northern Ireland to administer European programmes, but representation in the making of EU policy is a matter for the UK government, giving the Whitehall departments the lead role, with participation in working parties and at the Council of Ministers by invitation of the UK government. There are monthly meetings of the agricultural/rural affairs ministers in advance of Council of Ministers 
meetings. Officials are invited to working parties and there is supposed to be a good circulation of information. Scotland and England do not compete for European funding, as there is an agreement about how much of the various discretionary funds Scotland will get - in the case of the European Agriculture Guarantee and Guidance Fund this is 17 per cent (SCOTTISH EXECUTIVE, 2001).

These arrangements were intended to replicate the mechanisms for involving the territories in EU matters before devolution, when they were represented by territorial ministers (BULMER et al., 2002). They have worked so far because Scotland and Wales are governed by Labour-dominated coalitions not far removed politically from the government in London. Despite some complaints from Scottish interests about DEFRA failing to take the Scottish angle into account, the strategy of the Scottish Executive has been to play as a loyal part of the UK team and so keep their insider status and access to information.

\section{The Policy Networks}

Rural policy networks in England and Scotland are quite distinct. In both cases, policy has traditionally been led by departments of agriculture, with close client links to farming groups (GRANT, 1983) but now expanded into departments of rural affairs. Devolution has brought further change although, as it coincided with a change from Conservative to Labour government it is often difficult to distinguish which factor has caused a shift. The move to rural policy from agriculture should bring into the policy circles groups concerned with environmental, social and broader economic development issues and to some extent this has happened (WOODWARD and HALFACREE 2002). By the same token, it has brought more contention into the networks and exposed competing interests. The result was a period of optimism, as 
previously marginalized interests gained access, followed by some frustration as the reality of competition for policy and resources comes home.

Scottish devolution produced the UK's first Department of Rural Affairs, later combined with the environment ministry to form Scottish Executive Environment and Rural Affairs Department (SEERAD) ${ }^{1}$ intended to integrate approaches to the rural areas and ensure that the rural perspective was felt across the functional departments as well. In this, Scotland led the way. As late as 2000 the UK government was denying the need for such a department in England but had to follow suit in the wake of the Foot and Mouth crisis. In both countries there was opposition both from the farming lobby who feared the loss of their 'own' minister and from reformers who feared that the new departments would be dominated by the agricultural interest. (FAIRLEY, 2000; WARD, 2000). The Scottish Executive also established a Cabinet sub-committee on Rural Development to ensure a horizontal perspective and permit rural issues to be discussed by departments other than SEERAD. The Rural Core Network (formerly known as the Rural Agenda Steering Group) of civil servants provides the support and ensures that other Executive departments are kept informed through an internal circulation list.

A Rural Development Committee was set up in the Scottish Parliament with a remit including agriculture, fisheries, forestry, employment, transport, housing and poverty. As in the Executive, the idea is both to look at rural affairs as part of its own brief and to ensure that rural issues are taken into account by other committees.

Scotland has always had its own farming organizations, concerned with the particular conditions of farming in Scotland and the interests of Scottish as opposed to English farmers. The National Farmers' Union of Scotland (NFUS) has no affiliation with the National Farmers' Union (for England) although there is collaboration on 
European matters. In the Highlands and Islands, farmers are represented by the Crofting Foundation, with which NFUS co-operates. NFUS regards itself as a farming union, concerned with the agricultural industry, and is wary of being drawn into broader rural affairs matters. The Crofting Foundation has a wider remit, since crofting is seen as a way of life, and it has a close interest in land reform. The Scottish Rural Property and Business Association (formerly Scottish Landowners' Federation) is the equivalent of the Country Land and Business Association (formerly Country Landowners' Association) in England and represents the large estates. Previously regarded as a bastion of the landowning gentry, it has been affected by the transformation of many estates into capitalist enterprises. No longer protectionist, it welcomes foreign capital into what is now seen as a competitive industry. Dependent on the Conservative Party during the 1980s and 1990s, they were seriously affected by the change of government, the collapse of the Scottish Conservatives, and the arrival of the Scottish Parliament, where they have few natural allies and they needed to adapt quickly. The change in name of the landowners' associations, first in England and then in Scotland, is evidence of their changing role in the emerging rural policy agenda.

A prominent organization in recent years has been the Countryside Alliance, campaigning for the rural way of life, which has seized on proposals to ban foxhunting as symbolic of the threat to rural tradition. It has been able to mobilize large numbers of country dwellers in England, but its Scottish equivalent has had a rather low profile and does not have the same social base, although it has been given more autonomy since devolution.

There has been some progress in extending the rural policy community beyond farming, but change is limited and gradual. A Scottish National Rural Partnership 
(SNRP) was set up by, is chaired by, and has its agenda set by, SEERAD. This replaced the pre-devolution Rural Forum, disbanded when its members railed against its attempts to become more political without the express permission of all of its members. Although the new SNRP group includes a diverse range of interests it has been kept small by SEERAD, and some groups feel excluded. Critics complain that it is not possible to expand debate beyond the parameters set by SEERAD, although it is seen as a useful way of bringing groups together. In March 2002, in response to $A$ Forward Strategy for Scottish Agriculture, the Agriculture Strategy Implementation Group (ASIG) was set up to monitor the implementation of the document's action points and measure their success during the next two years. This group contains representatives of the major agricultural players in food production and processing, landowners, banking services, and representatives from food and consumer interests.

The latest addition to the list of cross sectoral groups is the Sustainable Development Forum founded in 2002. This network encourages liaison between groups participating in the rural debate, as well as with the Enterprise and Life Long Learning debate. Executive agencies such as Scottish Natural Heritage and Communities Scotland (the main housing agency) are also linking into new wider rural networks, participating in the integrated rural debate.

There is still concern by non-agricultural groups that mainstream policy is driven by agriculture, with broader rural development issues confined to a separate network. Some complain that the SNRP is not permitted to discuss agricultural issues in rural development debates, although in Executive documents agriculture is said to be the cornerstone of rural development. There appears to be some conflict and tension emerging between groups and the Executive, and some concern relating to agenda setting. As a result of these concerns and the suspicion that SEERAD was setting the 
agenda in the SNRP, World Wildlife Fund (Scotland) took the initiative in setting up a parallel Rural Dialogue group, which draws its membership from local government, executive agencies, social, heritage, agricultural, conservation, and environmental groups. This allows them, while still participating in SNRP, to broaden the debate. It was Rural Dialogue that began the campaign for a Scottish Rural Parliament, which was later taken over by the Scottish Civic Forum. As a result of these criticisms the Scottish Executive undertook a review of the SNRP in 2003. Ministers are still deciding whether or not to adopt a model of rural policy participation that resembles the Rural Affairs Forum for England, which sets its own agenda although its quarterly meetings are chaired by the Minister of State for Rural Affairs, and attended by relevant civil servants. It is made up of representatives from a wide range of rural interests including all of the main farming, business, government and voluntary organisations, who participate in subject specific sub-committees.

Rural affairs has also moved onto the local government agenda as demonstrated in February 2002, by the establishment of CoSLA's (Convention of Scottish Local Authorities) Rural Affairs Executive Group. This has been prompted primarily by the Community Planning system introduced in 2003. Community Planning involves partnership working at local level, consultation with the major groups within the local authority area and collaboration with Communities Scotland, the Health Boards, Police and Fire Boards, the local police force, Scottish Enterprise, Highlands and Islands Enterprise and, where relevant, Strathclyde Passenger Transport Authority. Social Inclusion Partnerships, previously run by Communities Scotland, are being placed under the Community Planning Partnerships. Voluntary groups have supported the idea but are suspicious of the lead role given to local government, which is sometimes seen as a rival. In practice, Community Planning has been less 
comprehensive than some expected, and is limited to co-operation on specific projects and services.

Tracking the changes in rural policy making and the actors involved since devolution in 1999 is complicated by the fact that rural policy officers tend to be relatively new in post or have only recently begun to consider rural policy. The lack of institutional memory makes it difficult to establish precisely the networks that existed before 1997/1999. Agriculture does still seem to dominate the debate but in the past five years new rural affairs networks have emerged, and new partnerships have been formulated between groups that, pre-devolution, would not often have come into contact with one another. We can divide them into four types, farming interests, environmentalists, social interests and economic development groups. Farming groups consider rural affairs to have a higher profile than before devolution. They claim that there is a new way of working and gathering responses, and that government is also attempting to produce solutions with them and that their input generally has had a positive impact. On the other hand, they seem to have less contact with UK politicians and civil servants, including the Secretary of State for Scotland than before, dealing almost exclusively with the Scottish Executive (LEBRECHT, 2002; WALKER, 2002).

Environmentalists also tend to feel that they have more influence after devolution, although they are still critical of some of the policies pursued. Groups interested in rural social policy issues complained in the early phase that rural was still a synonym for agriculture and that civil servants rely too much on farmers and other interested groups. These attitudes have slowly changed, however, over the five years as the new policy focus on social justice issues, on rural transport, and community sustainability has developed. 
Economic development networks, which predate devolution, seem to operate in parallel rather than within the new networks for rural policy. They come under the aegis of Scottish Enterprise (SE) or Highlands and Islands Enterprise (HIE) and the Department for Enterprise and Life Long Learning, whose strategic documents are $A$ Framework for Economic Development (SCOTTISH EXECUTIVE, 2000b) and Smart, Successful Scotland (SCOTTISH EXECUTIVE, 2001b). This does have a rural dimension and indeed is promoted by the Executive as a main policy instrument for rural areas, with a Rural Policy Group including representatives of SE and HIE, but they do seem to be in a distinct network from the social and environmental groups. They are linked into agricultural policy and refer to Scottish Agriculture: The Way Forward, but not to Rural Scotland: A New Approach, with its broader social framework. As so often in spatial policy, then, we see a disjuncture between the social and economic actors, a matter about which the Rural Affairs Committee of the Scottish Parliament has complained.

Scottish rural policy networks are clearly autonomous and not part of wider UK networks, which is not true in all policy fields (KEATING and LOUGHLIN, 2002). Few of the Scottish groups have any relationship with DEFRA, and few outside of agriculture have any formal links with counterparts in Wales, or Northern Ireland, although there is some informal contact on best practice, or information exchange, There are European networks on reform of the Common Agricultural Policy, Pillar II, and modulation. The European Rural Exchange Network, for which Dumfries and Galloway Council provides the secretariat, is concerned with rural affairs in the broader sense. Fishing, farming, environmental and conservation groups have been active in Europe. Local rural affairs groups seeking to influence the community 
planning initiative have more often looked to Scandinavian examples such as the Village Action groups, than to their counterparts in England or Wales.

\section{Redefining Rural Policy}

Early efforts at defining rural policy predate devolution, with White Papers in 1995-6 for England, Scotland and Wales. These were very similar, even to sharing identical paragraphs although there were some differences of emphasis (LOWE, 1996). Another Scottish White Paper was issued in 1998 after the change of government. Two further discussion papers were issued in 2000 in England and Scotland, looking at rural policy across the board, Rural Scotland. A New Approach (SCOTTISH EXECUTIVE, 2000a) and Our Countryside: The Future. A Fair Deal for Rural England, (DETR/MAFF, 2000) Then, following the Foot and Mouth outbreak, three reports were commissioned, The Foot and Mouth Disease 2001 - Lessons to be Learned Inquiry (ANDERSON, 2001), covering England, Scotland and Wales; the Policy Commission on the Future of Farming and Food (CURRY, 2002) covering England; and the Royal Society Inquiry into Infectious Diseases in Livestock, covering the United Kingdom. There was also a response to consultation on the rural white paper for England and the task force of Lord Haskins to look at the handling of Foot and Mouth (DEFRA, 2001). This gives us a lot of material from which to judge policy developments in England and Scotland.

Comparison of the two rural policy papers issued in 2000 shows a completely autonomous policy process. Some proposals that occur in both, or in related papers, such as the emphasis on diversification and derating, or restrictions on the right to buy council houses. The general approach, however, is quite different. The English paper is lengthy, tries to address myriad problems at the same time, and is replete with 
targets for public services and delivery. Strategically, it focuses on the need to control and shape development and emphasises the role of villages and market towns. This is the response of a government under pressure, which feels the need to produce results fast and it reflects the Whitehall fascination with quantitative targets for public service delivery. A rural advocate was appointed to bring rural issues to the attention of departments and all English policies are 'rural-proofed'. There is an emphasis on planning and development control and a focus on towns and villages. Most of the rest of the paper is about delivery of public services in areas which happen to be rural, rather than an analysis of the nature of rurality.

The Scottish paper is shorter, more reflective and less conclusive. It is an effort to start a process of thinking about rurality and how to model rural social and economic problems. There is a stronger emphasis on social inclusion than in the English paper, as well as an insistence on the importance of rural areas for Scottish national identity. There is an emphasis on economic development and less concern about housing pressures or the urban fringe. There are no service delivery targets and Scottish officials are unimpressed with the idea of 'rural-proofing'. Following the paper, working groups were set up on rural poverty and social inclusion and the SNRP was asked to look at questions of service delivery. The idea is to develop evidence-based policy and seek to redefine and model rural issues over the long term. Further analysis is being undertaken on neighbourhood statistics, education data and the Scottish Household Survey (SCOTTISH EXECUTIVE, 2003). A working party was set up under SNRP on rural social exclusion, which reported in 2001, again emphasizing the need for better data and definitions. A chapter on rural poverty was included in the Social Justice Annual Report Scotland, 2000 (PHILIP and SHUCKSMITH, 2000). 
Given this style of policy making, it will be some time before a clear policy emerges, but at this stage it seems that Scottish rural policy is headed out on its own policy line. Agriculture remains somewhat apart from the debate on broader rural policy. Rural Scotland. The Way Ahead emphasises that agriculture is at the core of the rural economy and the agricultural strategy published in 2001, A Forward Strategy for Scottish Agriculture, emphasises the need to look at rural development as a whole. Yet the actors involved in the two policy processes, both within government and among interest groups, remain rather distinct and the agricultural paper emphasises support for farmers. The farming lobby stayed out of the process of producing the rural policy paper and was not represented on the subsequent working groups.

Within the agricultural sphere, Scottish policy has emphasized the need to sustain the small hill farmers as an essential element in the countryside. English policy has placed more emphasis on diversification and the non-agricultural uses of the countryside. Lord Haskins, the Prime Minister's advisor on reform of agricultural policy in England, has continually attacked the farming industry and called for radical reform, in a way that has not happened in Scotland, although there have been discussions on the need for a 'Mac'Haskins review. Agricultural policy, of course, is highly influenced by the European level.

\section{European issues and agriculture}

European policies constrain the scope for policy differentiation in agriculture and rural affairs within the UK. In general EU programmes are applied uniformly across Member States but allow for a measure of differentiation. This has proved a difficult issue, as there is some disagreement on the scope of permissible variation. We have 
looked at three issues: the Rural Development Regulation; modulation and decoupling of agricultural support payments; and the regulation of genetically modified crops. Under the Rural Development Regulation, member states are obliged to submit Rural Development Programmes (RDPs) to the Commission as a condition of receiving support. Policies have diverged among member states, although there seems to have been relatively little move away from agriculture towards broader rural development issues (BRYDEN, 2000). The United Kingdom is the only state not to submit a programme for the whole state, but separate ones for England, Scotland, Wales and Northern Ireland. Both English and Scottish papers complain about the sparsity of European resources, even with modulation (see below). Certain measures not financed under the RDP are accommodated under national spending programmes, so that differences between RDPs may exaggerate policy contrasts. ${ }^{2}$ We can nevertheless detect clear differences in emphasis. The English programme has a stronger focus on diversification and environmental issues, while the Scottish one focuses on maintaining hill farming and on social inclusion. So the former identifies two key objectives - the rural economy and the environment, as mandated by the EUwhile the latter adds a social objective. The balance of resources is very different, with the English programme heavily geared to agri-environmental schemes while most of the Scottish money goes to Less Favoured Areas (MAFF, 2001; SCOTTISH EXECUTIVE, 2001a). Within the broad categories, England and Scotland have some similar programmes, but the emphasis varies. Both have a Rural Stewardship Scheme for environmental policies and England's Organic Farming Scheme is matched by Scotland's Organic Aid scheme. The Scottish programme, while agreeing on the need for diversification and for help in processing and marketing, notes the limited scope 
for diversification in Less Favoured Areas and leaves both these issues to national measures, given the shortage of money under the RDP.

Modulation, also part of the CAP reform, allows member states to convert part of the direct payments to farmers into broader rural development measures, increasing resources available for the Rural Development Plans. The UK was one of the first countries to adopt the measure in 2000 , starting at 2.5 per cent but planned to rise to 4.5 per cent. This provoked opposition in Scotland, Wales and Northern Ireland, whose farmers are more dependent on direct payments, although some Scottish environmentalists like it. For the Agenda 2000 reforms the line was taken that member states must apply modulation at a standard rate across the whole of their respective territories, with any territorial variation only on the basis of objective criteria, and not jurisdictional boundaries. NFUS's interpretation was that their rates of modulation could be varied within states (WALKER, 2002). Rural Affairs Minister, Ross Finnie merely told the House of Lords inquiry that his legal advice was that it was 'very difficult' (FINNIE, 2002). Modulation was finally agreed on the condition that the UK Treasury would provide the national matching funds required by the regulations, rather than requiring the territories to provide it out of their block grants. ${ }^{3}$ The Scottish minister also assured farmers that the modulation money would be cycled back into programmes from which they would benefit (LOWE and WARD, 2002), as indeed happened through the RDP. In England 94 per cent of modulation payments went to agri-environment measures while in Scotland just 22 per cent went to a slightly broader objective including environmental and social objectives. In 2001 the Policy Commission on the Future of Farming and Food (Curry Commission), set up by DEFRA to examine the future of farming and food signalled a further more in the same direction, recommending going up to 20 per cent. Although its brief only 
extended to England, it caused a storm in Scotland by extending this recommendation to the whole United Kingdom.

The next stage of CAP reform, in 2003-4 and involved two key elements: a rise in modulation; and a decoupling of agricultural payments from production, with farmers receiving a fixed sum based on acreage or on historic support levels, at the discretion of Member States. This time the Scottish Executive pressed in the negotiations for a clear right to differentiate policy and was able to achieve this, while keeping its existing proportion of agricultural spending. It subsequently undertook a consultation within Scotland as to how it should proceed, receiving just under three hundred responses. DEFRA's consultation in England, garnered around eight hundred responses (proportionately much fewer).

Farmers in Scotland generally continued to oppose modulation but the Scottish Executive nonetheless followed DEFRA in going for ten per cent, so attracting the corresponding Treasury support and leaving decisions on whether to raise the total further until the additional Treasury funding was secured. On decoupling, there was a clear policy divergence. While both Scotland and England chose to apply full decoupling, in Scotland this was based on historic payments, as favoured by farmers and opposed by environmentalists during the consultation. England, by contrast, opted to move to a flat-rate system by 2012 , but with different rates for two regions, the Severely Disadvantaged Area and the rest (later raised to three regions). Scotland, but not England, also opted to 'top-slice' the single payments to allow continued support for the beef sector. The Scottish Parliament's Environment and Rural Affairs Committee reported in June 2004 that it supported the Executive's moves to decoupling and pressed for a wider range of rural development measures. So policy is driven by EU decisions, with a strong role for DEFRA and the Treasury in 
determining the finance available, but with the Scottish Executive retaining an important margin of manoeuvre in balancing competing interests within Scotland.

Genetically modified crops (GM) involve all three levels of government. The Executive has the right to decide on trials of GM crops after consultation with the Advisory Committee on Releases to the Environment (ACRE), a UK-wide body. It has taken the view that under European law it cannot refuse permission on policy grounds, merely on scientific ones. Accordingly, the Rural Affairs Minister permitted GM trials in Scotland against strong opposition even within his own Liberal Democrat party. The National Assembly for Wales took a stronger line, voting to make Wales a GM free area, although the First Minister later admitted that it did not have legal authority for this (BULMER ET AL., 2002)). In England, the government is in favour of GM trials. On the larger question of GM planting, DEFRA launched a UK-wide debate on the whole issue - the Scottish Executive seemed content to let Whitehall take the political heat on this. The issue came to a head in 2004, when a decision had to be taken on allowing production of GM crops, at the UK level, starting with maize. Technically, the devolved administrations had a veto here for England as well as their own jurisdictions, since their consent was required for items to be put in the national seed list. This, however, is a 'nuclear' option, a power too strong to be used in normal politics. This time the Scottish Executive escaped with a very uneasy compromise. The Scottish Parliament would give its consent to planting across the UK of GM maize, while seeking a voluntary ban in Scotland, although it admitted that this was unenforceable. This is testing the informal mechanisms for resolving devolution issues to the limit. 


\section{Co-ordinated Policy. Foot and Mouth Disease}

The Foot and Mouth outbreak of 2001 caused a crisis in agriculture across Britain, with outbreaks in England, Scotland and Wales. While there was confusion about the division of responsibilities in Wales, the Scottish Executive had the prime responsibility, within the parameters of European law. Yet the common UK market in agricultural produce, the free movement of animals, and the ease of transmission of the disease between the neighbouring outbreak areas of Cumbria (England) and Dumfries and Galloway (Scotland) indicated a joint approach. There was therefore close co-ordination and joint policy making on critical issues like movement of animals, slaughter and the decision not to adopt vaccination.

While the broad policy line was consistent, differences in administrative arrangements produced a distinct response. According to the Anderson Inquiry (ANDERSON, 2002) the Scottish Executive was better co-ordinated and in closer touch with events on the ground than was the case in England, where MAFF had little contact with local governments and was not yet integrated into the Regional Office structures with other departments. Foot and Mouth is thus a good test of administrative devolution, but did not test the limits of political devolution, due to the determination of the territorial administrations to stick together. Had there been a serious disagreement on a key issue like vaccination or slaughter, as might happen in a future outbreak, this would have tested the ability to differentiate policy in a unified market and travel area. As it was, Scottish farmers complained that the export ban was not lifted earlier in Scotland, given their success in containing the outbreak. In dealing with the longer term implications of Foot and Mouth disease, European considerations came back in, with DEFRA seeking a change in regulation allowing it to buy up sheep 
quota, and then proposing to work with the devolved administrations on whether to apply this (DEFRA, 2001)

\section{Separate Policies}

On three significant issues, Scotland has been able to move ahead on its own without reference to UK or European levels. Land reform is a matter in which there are distinct Scottish traditions, demands and history and preparations for legislation were put in train after the election of the UK Labour Government in 1997, in anticipation of devolution. An early piece of legislation completed the abolition of feudal land tenure in Scotland and was relatively uncontroversial. More important politically was the collective right to buy given to tenants of large estates in the Land Reform Act. This takes two forms. Tenants of Scottish estates are given a right collectively to buy their estate when it comes onto the market. Several groups of tenants have already done this through the market, with government assistance through a Scottish Land Fund; under the Act this becomes a statutory right. Crofters (as defined strictly in legislation $)^{4}$ have a stronger right, being able to buy out their landlord at any time, an extension of an earlier right to buy their own crofts individually. The same Act includes stronger rights of access to land for ramblers, paralleling legislation in England. The Land Reform Bill proved immensely complex and was subject to lengthy consultation and study, with input from a wide variety of interests but these were all within Scotland. The Scottish Landowners Federation was opposed but saw the inevitability of the measure. The NFUS was more even-handed, since it represents both landowners and tenant farmers. Crofting interests were in favour and sought to extend the scope of the bill, securing a concession allowing the purchase of fishing rights contained within crofting land. It was not possible to shift the issue to the UK 
level, since the matter lies entirely within the competence of the Scottish Parliament and there are few implications for other parts of the United Kingdom. European issues surfaced as a consequence of the Scottish Executive's concern that compulsory purchase could conflict with the European Convention for the Protection of Human Rights, and great care was made to ensure that the legislation was in conformity. National Parks were first created in England and Wales after the Second World War. Scotland at that time was excluded, largely because of the power of the big landowners. The low priority of the issue and lack of legislative time meant that it was never taken up subsequently, but this was an issue on which the Scottish Parliament could legislate without reference to broader UK considerations. In the first session, legislation was passed and national parks are not being set up. This might be seen as a case of convergence, with Scotland catching up to England and Wales, yet the legislation contains significant differences from its counterpart south of the border and is the product of a purely Scottish debate.

Abolition of fox hunting is a favoured cause within the urban Labour Party across Great Britain but has raised strong emotions since it is a proxy for bigger social cleavages. Many see the issue as a class one, fox hunters being portrayed as a mixture of old gentry and nouveaux riches seeking upward social mobility in the arcane British class system, although hunters themselves dispute this, pointing to the existence of popular farmers' hunts. It is also an urban-rural issue, with urban liberals seeing hunting as a survival of rural barbarity and hunters themselves insisting that it is part of their essential culture. Beside these emotive concerns, technical considerations carry little weight. As an issue of conscience this is something regulated by private members' bills on a non-party basis, with a free vote in the legislature. After 1999 it became obvious that there were majorities for abolition both 
Westminster and the Scottish Parliament, but the Labour Government seemed reluctant to upset the rural lobby by pushing legislation for England through. Accordingly, they allowed the bill to be sabotaged by parliamentary obstruction and the House of Lords. The Scottish legislation had a difficult time in the Rural Affairs Committee, where it was criticized for being badly drafted and ill-thought out but eventually it passed. Hence, from 1 August 2002 hunting with hounds is illegal in Scotland but legal in England and Wales. ${ }^{5}$

\section{Conclusions}

Rural policy can be defined in various more or less encompassing ways. As it has evolved in the United Kingdom, the most important strands are economic development policy, environmental issues and social exclusion and inclusion.

Within this framework, a distinct rural policy agenda is developing in Scotland, although constrained by European policies and conditions. Some of this reflects objective conditions, such as the relatively clear differentiation between urban and rural areas and the lesser development pressures. The Highlands and Islands present specific concerns, as does the predominance of marginal agriculture. Policy networks are increasingly differentiated and autonomous of their UK counterparts, with more policy capacity emerging at the Scottish level. Devolution has also shifted power within Scotland, away from groups that were protected within the old structures, hence the movement on land reform, national parks and abolition of fox hunting. Groups and networks still tend to be sectoral and tied into different departments and programmes of the Scottish Executive. Farming groups still enjoy the strongest position within the SEERAD networks and have tended to take a restricted view of their role, although recognizing that this may have to change in the future. Non- 
farming groups criticize a lack of political will to broaden the rural debate by the Executive, and the lack of 'joined-upness', given that rural development is a crosscutting policy, and that there is a Minister for Rural Affairs, a Scottish Executive Department dealing with Rural Affairs, and a Cabinet sub-committee on rural affairs, shadowed by the Rural Core Network. Imposing a rural, territorial definition on a range of sectoral policies would require a powerful agency 'owning' the rural brief. This is happening only slowly in Scotland as in England. Within SEERAD, rural policy advocates have also tended to be weaker than the agricultural specialists and face a challenge trying to inject a rural dimension across other departments.

Reappraisal of rural policy is hampered by lack of data and analysis on rural problems and opportunities, in comparison with the amount of work done on other spatial policies. SEERAD has had limited statistical evidence to provide the hard data necessary for evidence based policy making in rural affairs. It took almost two years to produce a definition for rural that could be used across the departments of the Scottish Executive.. Lack of data and modelling hampered efforts to include the social dimension in rural policy, although this is gradually being remedied. In England, where the scope of rural policy is even larger and more encompassing, groups seem to be voicing similar complaints about a lack of joined-up thinking. In practice many of these problems within England are likely to be resolved at the regional level, where rural policy is emerging as a key theme and conceptualizations of rurality need to be sensitive to regional differences (WARD, LOWE and BRIDGES, 2003).

Scotland exhibits a distinct policy style, found also in other areas of policy making since devolution (KEATING, forthcoming). The weakness of policy-making capacity at the centre has led to more reliance on professional networks, and hence a more negotiated style of policy-making. There has been a less confrontational attitude 
towards farmers and a strong emphasis on keeping agriculture going, especially the hill farms. There is a greater role for local government, which has not always played well with other groups wanting to realign the networks and shift policy priorities. This policy style can be praised as involving 'stakeholder involvement' or criticized as pandering to 'vested interests' depending on whether the observer likes or dislikes the results, but it is certainly different from what happens in Whitehall. Scotland has not had the highly politicized 'rural crisis' that appeared on the political agenda in England in the early 2000s and lacks the politicized rural lobby. The lesser exposure to the sequential BSE and Foot and Mouth crises also lessened the pressure. This permitted rural policy to be developed through a research focus and an effort to redefine the issue, as the policy papers reviewed above show.

Policy divergence under devolution has not proved to a matter of rapid and radical change, in this or other fields. Rather there has been a gradual adjustment of policy networks within Scotland and a testing of what Scotland can do within the UK and the EU. On specific questions, Scotland has shown that it can go its own way in matters without cross-border spillovers or European implications. Other areas of policy making remain intergovernmental and Europeanized and here the Scottish Executive has had to explore the limits to its role and influence. Judging these limits is complicated by the fact that Scotland has had an administration that has preferred to remain close to Whitehall in order to maintain its insider status and thus retain a position within UK and, by extension, European networks. So there has not been a political will to challenge the centre but a consistent search for compromise, as in the case of GM crops. Nor does policy divergence necessarily mean Scotland diverging from the status quo. In a number of fields, the weight of Scottish opinion and interest has led it to retain old ways of working, while England has moved. In other cases, 
devolution has even permitted policy convergence, as ideas have diffused through the various territories.

We are grateful to Mark Shucksmith for advice in the earlier stages of this work and to Alan Greer for comments on an earlier version of the paper.

\section{References}

ANDERSON (2002), Foot and Mouth Disease 2001: Lessons to be Learned Inquiry, chairman Dr Ian Anderson.

BRYDEN J.M. (2000) 'Is there a "New Rural Policy"?' International Conference: European Rural Policy at the Crossroads, June 2000, University of Aberdeen, Arkleton Centre.

BULMER, S., M.BURCH, C.CARTER, P.HOGWOOD and A.SCOTT (2002), British Devolution and European Policy-Making. Transforming Britain into MultiLevel Governance, London: Palgrave.

CALLENDER, R. (1997), How Scotland is Owned, Edinburgh: Canongate.

CURRY (2002), Report of Policy Commission on the Future of Food and Farming, Farming and Food: A Sustainable Future, London:Cabinet Office.

DEFRA (2001), Department of the Environment, Food and Rural Affairs, England's Rural Future: Government Response to the Reports by the Rural Task Force and Christopher Haskins. Progress on Implementing the Rural White Paper (London: DEFRA).

DEPARTMENT OF ENVIRONMENT. TRANSPORT, AND THE REGIONS AND DEPARTMENT OF AGRICULTURE, FISHERIES AND FOOD (DETPR/ MAFF) (2000), Our Countryside: The Future. A Fair Deal for Rural England. 
FAIRLEY, J. (2001), 'Scotland's New Democracy: Opportunities for Rural Scotland?', Scottish Affairs, 34, 45-67.

FINNIE, R. (2002), Oral evidence to the House of Lords Select Committee on the Constitution, 15 May 2002, Devolution: Inter-Institutional Relations in the United Kingdom, EvidenceComplete to 10 July 2002, HL147.

KEATING, M. (2000), Rural Governance. The International Experience, Agricultural Policy Coordination and Rural Development Research Programme Research Findings No. 9, Edinburgh: Scottish Executive Central Research Department.

KEATING, M. (forthcoming), The Government of Scotland. Public Policy Making after Devolution, Edinburgh: Edinburgh University Press.

KEATING, M. and BLEIMAN, D. (1979), Labour and Scottish Nationalism, London: Macmillan.

KEATING, M. and LOUGHLIN, J. (2002), Territorial Policy Communities and Devolution in the United Kingdom, EUI Working Papers, 2002/1, Florence: European University Institute.

LEBRECHT, A (2002), Oral evidence to the House of Lords Select Committee on the Constitution, 14 April, 2001, Devolution: Inter-Institutional Relations in the United Kingdom, EvidenceComplete to 10 July 2002, HL147.

LOWE, P. (1996), 'The British Rural White Papers', Working paper 21, Centre for Rural Economy, University of Newcastle upon Tyne.

LOWE, P. and WARD, N. (2002), 'Devolution and the Governance of Rural Affairs in the UK', in John Adams and Peter Robinson (eds), Devolution in Practice. Public Policy Differences within the UK, London: IPPR. 
MACAULAY LAND RESEARCH INSTITUTE (2001), Agriculture's contribution to Scottish society, economy and environment. A literature review for the Scottish Executive Rural Affairs Department and the CRU, Aberdeen: University of Aberdeen.

MAFF (2001), England: Rural Development Programme, 2000-06.

PHILIP, L. and SHUCKSMITH, M. (2000), 'The character of rural poverty in Scotland, in Scottish Executive, Social Justice Annual Report Scotland, 2000. SCOTTISH EXECUTIVE (2000a), Rural Scotland. A New Approach. SCOTTISH EXECUTIVE (2000b), A Framework for Economic Development, Edinburgh: Scottish Executive.

SCOTTISH EXECUTIVE (2001a), Rural Development Plan for Scotland.

SCOTTISH EXECUTIVE (2001b), A Smart. Successful Scotland. Ambitions for the Enterprise Network, Edinburgh: Scottish Executive SCOTTISH EXECUTIVE (2002), A Forward Strategy for Scottish Agriculture. SCOTTISH EXECUTIVE (2003), Rural Scotland: Taking Stock. SCOTTISH OFFICE (1998), Towards and Development Strategy for Rural Scotland. SHUCKSMITH, M. (2000), Exclusive Countryside? Social Inclusion and Regeneration in Rural Britain, London: Joseph Rowntree Trust.

WALKER, J. (2002), Oral evidence to the House of Lords Select Committee on the Constitution, 14 April, 2001, Devolution: Inter-Institutional Relations in the United Kingdom, EvidenceComplete to 10 July 2002, HL147.

WALLER, R. and CRIDDLE, B. (2002), The Almanac of British Politics, seventh edition, London: Routledge. 
WARD, N. (2000), 'A Department for Rural Affairs; Radical Reform or Red

Herring?', Working Paper 52, Centre for Rural Economy, University of Newcastle upon Tyne.

WARD, N., LOWE, P. AND BRIDGES, T. (2003), 'Rural and Regional

Development: The Role of the Regional Development Agencies in England, Regional Studies, 37, 201-13.

WIGHTMAN, A. and HIGGINS, P. (2000), 'Sporting Estates and the Recreational

Economy in the Highlands and Islands of Scotland', Scottish Affairs, 31, 1-17.

WOODWARD, R. and HALFACREE, K (2002), 'Influences on Leadership and

Local Power in Rural Britain', in Keith Halfacree, Imre Kovách and Rachel

Woodward (eds), Leadership and Local Power in European Rural Development, Aldershot: Ashgate.

This article draws on work being done under the ESRC initiative on Devolution and the project on Nation and Region in the United Kingdom at the Constitution Unit, University College London, funded by the Leverhulme Trust.

\footnotetext{
${ }^{1}$ Environment and agriculture had first been brought together in a Scottish Office reorganization following the Rural White Paper of 1996.

${ }^{2}$ Indeed RDPs, like Structural Fund programmes, are seen less as planning documents than as an instrument for drawing down previously agreed sums from Brussels. The fungibility of public expenditure programmes makes it difficult for them to be attributed clearly. This may also explain why
} 
the Scottish RDP was subject to so little consultation, being used mainly as a vehicle to fund existing priorities.

${ }^{3}$ Had the Treasury provided the money through the standard Barnett formula, Scotland, Wales and Northern Ireland would have got only their population-related share.

${ }_{5}^{4}$ A croft was once defined as 'a small piece of land surrounded entirely by legislation'.

${ }^{5}$ The legislation was later found to contain the anomaly that foxes can still be hunted with dogs, as long as they are finally despatched with a gun. So the hunts continue. 